\title{
福祉機器を切り替えて使用するためのターンテーブルの開発 \\ Development of a Turn Table for Handicapped Person to Switch Welfare Equipments
}

\author{
○早田 耳 ${ }^{1}$ ，小出 瑞康 ${ }^{1}$ ，シャハリアル アハメド \\ 1. 新潟産莱大学 産菜システム学部 \\ OMakoto Hayata', Mizuyasu Koide ${ }^{1}$ and Shahriar Ahmed' \\ 1. Niigata Sangyo University Faculty of Industrial Systems
}

\section{1. 粠司}

日本では障害者への瓄境の整備が進んできており，社会復帰 も可能である. しかしながら, 四肢麻連者についてはいまだに就 労に関しては難しく, 就労以外の社会参加, QOL の向上なども 必要になってくる. 現在は, インターフェースの充実により, 四肢 麻㢆者でも動かすことの可能な，電動車いすなどが開発されてい る.こうした機器が増えていくことが, 四肢麻瘴者の生きがいの選 択肢を增やしていくことにつながる 1 。

肢体不自由者, 特に全身不随者は健常者のように手を使って 文字や絵を描くことができない.しかしながら，上で述べたように， 肢体不自由者は福祉機器の支援を受けて, 執筆活動や読書など さまざまな活動を行うことができるようになる. 現在,一つの機器で すべてをこなせる万能の福祉機器は存在しない. したがって, 執 筆や読書など, それぞれの活動には専用の福祉機器が必要であ り,肢体不自由者はこれらを切り替えて使用する必要がある.こう した作業の切り替忘は, 肢体不自由者には非常に困難で介助者 の助けが必要になる.

そこで, 本研究ではこれらのいくつかの作業を並行して行うこと を可能にするため, 肢体不自由者自身が自分で福祉機器を使い 分けることのできるターンテーブルの開発を行った. 使い分ける 機器としては,ここでは絵を描くための画板, 本のページめくり機, PCを想定している.

\section{2. ターンテーブルの設計と作}

Fig. 1 にターンテーブルの模式図を示す. テーブル上に設監 する機器の大きさおよび利用者が度るベッドの大きさからテーブ ルの直径は $900 \mathrm{~mm}$ とした. 今回の開発では, テーブルを回転さ せる動力として低回転でトルクの大きいギヤードモータを用いた. Fig. 1 に示されるように, モータはテーブルの下, 中央に設膡さ れる. テーブルは $15 \mathrm{~s}$ で1周するものとし, 1 周中の速度変化を設 定した.モータの出力とギヤ比は, 先に設定したテーブルの速度 変化から求めた角加速度, テーブルとテーブル上に設㯰される 機器の惯性モーメントから求め, それぞれ $30 \mathrm{~W}, 1: 10$ とした。テ ーブルは，下部に取り付けられた5つのキャスターによって支持さ

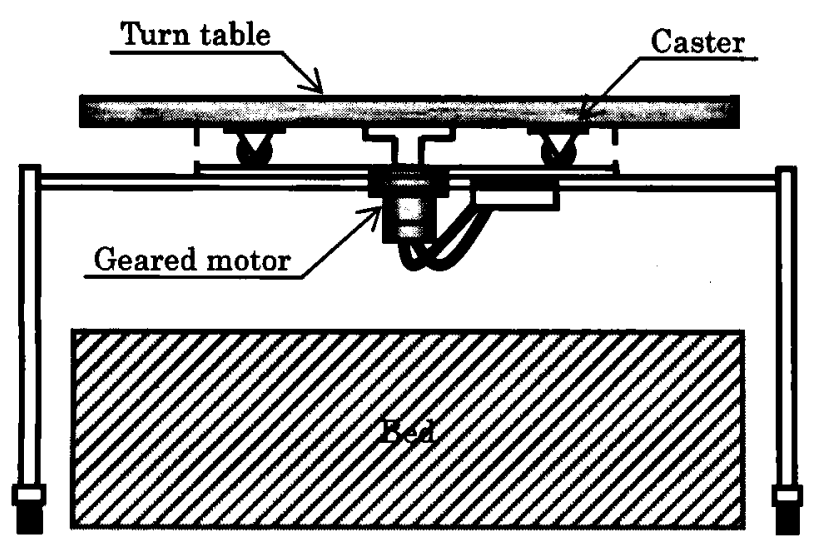

Fig. 1 Schematic diagram of the turn table
れ、駆動軸には荷重がかかからないようにした.

テーブルを回転させるためのスイッチは, 右回転用と左回転用 の2つのリミットスイッチを設圆した. 使用者は口にくわえた棒等で スイッチを押すことになる.このスイッチは押している間, テーブル が回転し、はなすと止まるよう調整されている。

\section{3. 結果}

Fig. 2 に完成写真を示す.はじめに, 動作検証を行った.テー ブル上に $20 \mathrm{~kg}$ のおもりを乗せ試験運転を行い, 回転することを 確認した.

テーブルの動作確認を行った後, 協力者宅に装置を持ち込ん でテーブルの回転速度，設圈位圆およびスイッチの位㯰の検討 を行った. ターンテーブルはベッドをまたぐように設㯰される(Fig. 1). ターンテーブル上には機器が設置されるため, テーブルをで きる限り低く設置する必要があることを確認した. ただし, Fig. 1 のようにテーブルの下には駆動用のモータが設䈯され, 使用者の 体がテーブルの下に入り込んでいるため，単純にテーブルを下 げることができない。

また，操作用のリミットスイッチの位置調整を行った. ロにくわえ た捧を直線的に押し出す動作は難しいため，ヒンジ・レバー型の スイッチを用い，首を横に動かすことでスイッチ操作ができるよう にした. しかしながら，この操作方法では少なからず棒をくわえた 前歯に負担がかかるため, 非接触のスイッチを用いるなどの改良 が必要である.

\section{4. まとめ}

本研究では肢体不自由者自身が自分で福祉機器を使い分け ることのできるターンテーブルの開発を行った. 協力者とともに装 置の検討を行った結果, 複数の福祉機器を使い分けることができ， その有効性を確認することができた. しかしながら, テーブルの設 置位直，回転速度，操作方法については，駆動方法の見直しな ども含めて検討していく必要がある.

\section{5. 当文柲}

1) 武田宣子, リハビリテーション看護 第5版, 医学畫院, 2005

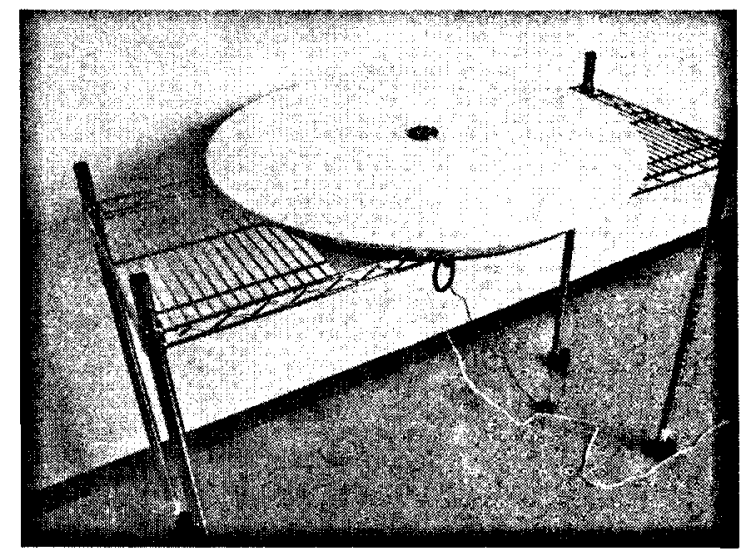

Fig. 2 Photograph for the turn table 